\title{
Novel Strategies for Ultrasound Diagnostics and Therapeutics by Micro/Nanobubbles
}

\author{
RYO SUZUKI ${ }^{1}$, YUSUKE ODA ${ }^{1}$, DAIKI OMATA ${ }^{1}$, \\ YOSHIKAZU SAWAGUCHI ${ }^{1}$, MUTSUMI SEKI ${ }^{1}$, HITOSHI URUGA ${ }^{1}$, \\ TOMOYUKI NAOI ${ }^{1}$, YOICHI NEGISHI $^{2}$, KAZUO MARUYAMA $^{1 *}$
}

\author{
${ }^{1}$ Laboratory of Drug and Gene Delivery System, Faculty of Pharma-Sciences, Teikyo University, 2-11-1 Kaga, \\ Itabashi, Tokyo 173-8605, Japan \\ ${ }^{2}$ Department of Drug Delivery and Molecular Biopharmaceutics, School of Pharmacy, Tokyo University of \\ Pharmacy and Life Sciences, Tokyo 192-0392, Japan
}

\begin{abstract}
Theranostics is a novel concept that combines diagnostics and therapeutics. In the field of diagnostics, various pieces of medical equipment are commonly used, such as X-ray computed tomography, magnetic resonance imaging, positron emission tomography, and sonography. Because of physical energy within these different pieces of equipment, ultrasound is a useful tool for theranostics, and it is particularly suitable for diagnostics with sonography and therapeutics with hyperthermia for cancer. Recently, microbubbles were recognized as an effective type of agent for imaging blood flow in tumors. In particular, Sonazoid, which is a commercially available microbubble, has been used for detection of hepatic tumors. In addition, microbubbles are useful tools for theranostics because they can be used not only as an ultrasound contrast imaging agent but also as an enhancer for hyperthermia with therapeutic ultrasound. To improve the accessibility of microbubbles in the deep tissue, researchers are developing various types of smaller bubbles such as the submicron-sized nanobubble. We have also developed novel liposomal bubbles (Bubble liposomes), which consist of entrapped perfluoropropane gas in a lipid bilayer. Bubble liposomes have several advantages over existing technologies, such as they can be used as ultrasound imaging agents, it is easy to modify the targeting molecules on their surfaces, and they are highly applicable for the enhancement of hyperthermia with therapeutic ultrasound. In summary, the combination of ultrasound and micro/nanobubbles would allow for the development of an ideal method for noninvasive theranostics. In this review, we will introduce recent developments on ultrasound theranostics using microbubbles and nanobubbles such as Bubble liposomes.
\end{abstract}

Key Words: ultrasound, hyperthermia, nanobubbles

\section{はじめに}

近年，治療 (Therapeutics) と診断（Diagnostics）を合わせた新たな言葉としてセラノスティックス

Received 5 April, 2013, Accepted 7 May, 2013. *Corresponding author; Tel, +81-3-3964-8239; Fax, +81-3-3964-8243;

e-mail, maruyama@pharm.teikyo-u.ac.jp

doi : $10.3191 /$ thermalmed.29.37

(C) 2013 Japanese Society for Thermal Medicine 
(Theranostics) が注目されている.また，2011年には，雑誌“Theranostics” (チーフエディター： Xiaoyuan (Shawn) Chen 博士 (National Institute of Biomedical Imaging and Bioengineering (NIBIB)) が 創刊された ${ }^{1)}$.この雑誌のインパクトファクターは 7.0 (2013 年 4 月現在) と高く, この数值からも本分 野の注目度は高いことがわかる．このセラノスティックスの定義として，(1)特定の薬物に著効を示す患 者を診断により選別した上での薬物治療, (2)診断と治療を同時に行うシステムの 2 つがある. (1)の例と して, 乳がん治療において, あらかじめ乳がん細胞上にヒト上皮細胞増殖因子レセプタータイプ 2 (HER2) が発現していることを診断し，ハーセプチン (抗 HER2 抗体) 治療を行うことが挙げられる. このような患者にとって有効な治療法を選択するための診断は, 治療の最適化のために非常に重要であ る.また，(2)の例として，超音波イメージングガイド下での穿刺によるがん治療などが挙げられる．さ らに, 診断薬と治療薬を同時に搭載した薬物キャリアーを利用し, 診断後すみやかに治療を行うことの できるシステムの構築が試みられている. しかし, (2)関して現時点では発展途上であり, セラノス ティックスの理想的な概念を実現化すべく研究・開発が進められている.

現在, 診断装置としてX線 Computed Tomography (CT), Magnetic Resonance Imaging (MRI), Positron Emission Tomography (PET), 超音波などが臨床応用されており, 各装置で様々な特徵があ る。その中で超音波造影装置は, 管理区域が不要, 小型でベッドサイドにも運搬可能, 比較的安価, リ アルタイムイメージングが可能などの多くの利点があり注目されている．また，最近では標的部位に体 外からピンポイントに超音波のエネルギーを集束できる治療用超音波装置 (強力集束超音波 (HIFU)) が 開発され，新たながん治療法として期待されている．このように超音波は，治療と診断のための装置が 揃っており，セラノスティックスを構築する上で有望な医療用エネルギーとして捉えられる2). そこで 著者らは, セラノスティックス構築のための医療機器として超音波診断・治療システムに着目し研究を 進めている，本稿では，この超音波を利用したセラノスティックスに関して，著者らの取り組みを交え 概説する.

\section{超音波造影における超音波造影剤の利用}

超音波造影装置および画像構築技術の飛躍的な進歩に伴い，様々な組織を非侵襲的かつ高解像度で撮 像することできる．また，ドップラー効果を利用することで，血流の速度や方向をリアルタイムに把握 することも可能である. さらに最近では, 胎児の撮像に対し 3D/4D イメージングが可能となってお り, 子宮内の胎児の表情や動きを鮮明に表示できるようになっている，一方で，超音波造影装置のみで は撮像しにくい生体内器官も存在する。一般に血流の造影では, ドップラー効果により比較的血流が豊 富な血管や太い血管を特定することができるものの，微小血管の観察や組織内の血行を評価することは 困難とされている，そこで登場したのが，超音波造影剂であるマイクロバブルである，このマイクロバ ブルは, 造影用超音波照射により共振し, 非線形的挙動をする. この時, 照射した超音波の周波数より 高周波の超音波が発生する．現在では，この高周波成分を利用して画像化するハーモニックイメージン グ法が，がんなどの異常組織画像の強調や血流診断の精度向上に利用されている.

超音波造影剤を利用した超音波造影の歴史は古く, 1968 年頃からマイクロバブルの利用が報告され ている ${ }^{3}$. 当初は, $\mathrm{CO}_{2}$ ガスや空気の入った注射筒と生理食塩水, 糖液, 粘稠液 (高張糖液, 脂肪乳剂 など）の入った注射筒を三方活栓で連結し，意図的に気泡が混入するようにシリンダーを前後させてマ イクロバブルを用時調製していた (用手攪拌法)，このマイクロバブルは，肝腫瘍の動脈血行動態を観察 するために動脈内投与により用いられており, 動脈血行動態の観察においてはX線 CT や MRI ๖り優 れた方法として評価されていた。 しかし, このマイクロバブルの安定性は悪く, 静脈内投与ではその造 
影効果は右心室に血液が移行するまでで消失してしまい，左心系の造影はできなかった，そのため，左 心系での造影を行う場合は，動脈にカニュレーションしてマイクロバブルを投与する必要があり，侵襲 的な方法であった。 その後 1999 年に本邦で経静脈性超音波造影剂としてレボビスト (第一世代の超音 波造影剤) が販売され，マイクロバブルを使用する場合でも非侵襲的な超音波造影検查が受けられるよ うになった ${ }^{4)}$. このレボビストはガラクトース・パルミチン酸混合物を注射用水で懸濁したマイクロバ ブルで，空気の微小気泡がパルミチン酸で被覆された構造を有している。このレボビストは，用手攪汼 法で調製されていたマイクロバブルより血中存在期間が延長され，数分間にわたって全身循環系を循環 できる，これにより，右心腔・左心腔のみならず種々の臓器・血管における造影が静脈内投与でできる ようになった.

レボビストを用いた超音波造影では，高い音圧の超音波で気泡が崩壊する時に発生する高調波成分 (ハーモニック信号) を造影画像としている (高音圧系造影剤). 要するに, 超音波造影装置から照射され る超音波によりマイクロバブルを壊しながら造影をしている．そのため，マイクロバブルが断層面に溜 まるのを待って撮像するような撮像夕イミングの工夫が必要であった。一般に血管イメージングでは 0.2 0.5 秒，灌流イメージングでは 1 5 秒の間歇時間が必要とされている. この点を改善したのが, 第二世代の低音圧系造影剤のソナゾイドである.ソナゾイドはシェル (殼) に水素添加卵黄フォスファ チジルセリンナトリウムを用い, 内包するガスに難溶性フッ化炭素ガス (パーフルオロブタン) を用い た直径 2 3 $3 \mu \mathrm{m}$ のマイクロバブルである (Fig. 1A)．このマイクロバブルは，照射超音波に対する安定 性および生体内での安定性が共に高い。超音波検査時にソナゾイドを静脈内投与し，低〜中音圧の超音 波を照射してマイクロバブ ルを共振させることによっ て生じる信号を画像化す る.これが第二世代の超音 波造影剤である、マイクロ バブルを破壊せずに造影が 可能であるため, リアル夕 イム性に優れ繰り返しの造 影が可能である. 肝臓の超 音波造影を例に説明する と, ソナゾイドの静脈内投 与 $10 \sim 15$ 秒後に肝動脈が 造影され, その数秒後に門 脈が造影される.この時, 肝臓内に腫瘍があれば，腫 瘍内の血流も造影可能とな る (血管イメージング $)^{5}$. ソナゾイドのシェルはフォ スファチジルセリンである ことから，フォスファチジ ルセリンに対するレセプ ターを有するクッパー細胞

(A)

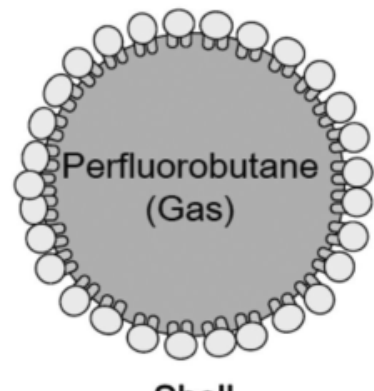

Shell

Phosphatidylserine
(B)

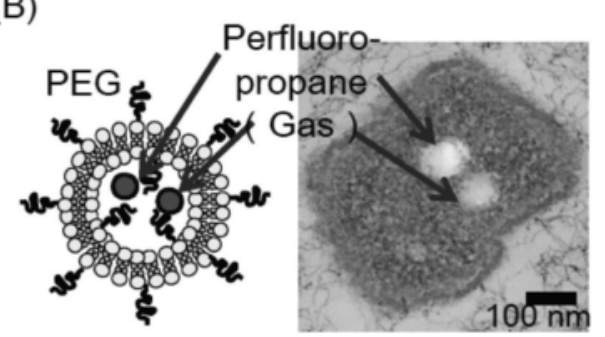

Shell

Liposome

(Phosphatidylcholine、PEG-modified phosphatidylethanolamine )

(C)

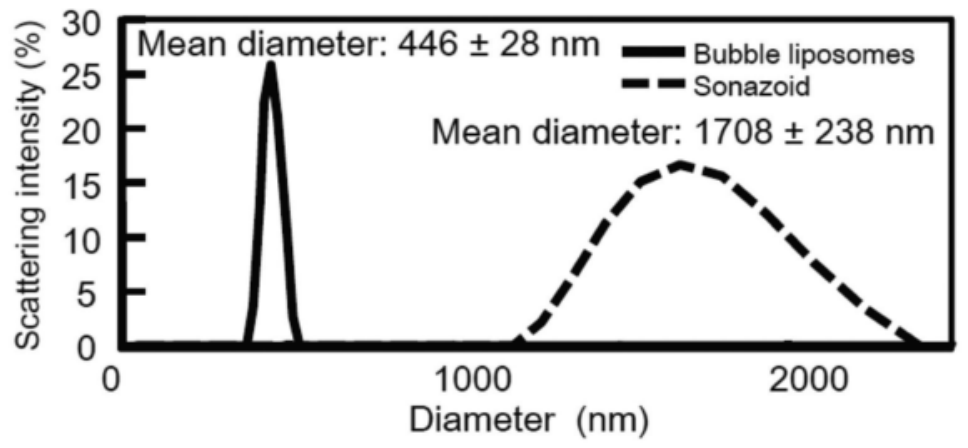

Fig. 1. Comparison of Bubble liposomes and microbubbles (Sonazoid). Schematic of (A) Bubble liposomes (B) Sonazoid with an image taken via transmission electron microscopy $(\times 50,000)$ Sonazoid and $(\mathbf{C})$ Size distribution of Bubble liposomes and Sonazoid as measured by dynamic light scattering. 
がソナゾイドを領食する．そのため，ソナゾイド静脈内投与 10 分後に肝臟を超音波造影すると大半の マイクロバブルがクッパー細胞に取り込まれた像が得られる。すなわち正常な肝臓であれば肝蔵全体に クッパー細胞が分布しているため, 肝臓全体が高エコーを呈する. 一方, 肝臓内に腫瘍が存在した場 合，一般に腫瘍部分でクッパー細胞が欠落しているため，その領域が欠損像として描写される(クッ パーイメージング $)^{6-8)}$. ソナゾイドはクッパー細胞へのアクティブターゲティング型マイクロバブルと して世界に先駆け 2006 年 10 月に日本で認可された有望な超音波造影剂であり, 肝腫瘤性病変のイメー ジングに利用されている．また，ソナゾイドが乳腺領域でも正常組織と異なる血管構築を有する乳房腫 瘤性病変の検出や良悪性の鑑別診断に有用であることも示され ${ }^{9}$,, 2012 年 8 月に「超音波検査における 乳房腫瘤性病変の造影」を効能・効果として追加承認を得ている.

\section{標的指向型超音波造影剤の開発}

日本国内で認可されている超 音波造影剤は, レボビストとソ ナゾイドであるが, 前項までで 示したようにマイクロバブルの 安定性やリアルタイムイメージ ングの観点から, 臨床現場では 第二世代の超音波造影剤である ソナゾイドが主に利用されてい る. Table I には世界で臨床応

Table I. The list of approved microbubbles.

\begin{tabular}{ccccc}
\hline Brand name & Shell & Entrapping gas & Country & Size $(\mu \mathrm{m})$ \\
\hline Levovist & Galactose & Air & EU, JP & $2-4$ \\
Optison & Albumin & Perfluoropropane & US, EU & $3-32$ \\
Definity & Lipids & Perfluoropropane & US & $1.1-20$ \\
Imagent & Lipids & Perfluoropropane & US & 5 \\
Sonovue & Lipids & Sulforhexafluoride & EU & 2.5 \\
Sonazoid & Lipids & Perfluorobutane & JP & $2-3$ \\
\hline
\end{tabular}
用されている超音波造影剤の一

覧を示す．この中ではソナゾイドが唯一特定細胞に選択的に集積する能力を有する標的指向 (アクティ ブターゲティング) 型のマイクロバブルである. このソナゾイドの日本での認可も相まって, アクティ ブターゲティング型マイクロバブルの研究が世界中で行われるようになった．実際に，抗体，ペプチド や糖鎖など様々な標的指向性分子を修飾した様々なマイクロバブルの開発が進められている．そのなか で最も進んでいるのが，Bracco imaging 社（ミラノ，イタリア）の血管内皮細胞増殖因子レセプター2 (VEGFR2) に対し特異的に結合するぺプチドを修飾したマイクロバブル (BR55) である10,11). この BR55 は，がん組織の新生血管に対して選択的に集積するマイクロバブルであり，がんの早期超音波診 断や抗腫瘍血管療法における治療効果の評価への応用が見込まれている ${ }^{12}$. また, Targeson 社 (サン ディエゴ，米国) はビオチン修飾マイクロバブルにストレプトアビジンを介してビオチン化抗体を修飾 するシステムを構築し試薬として市販している．このシステムはアビジンを使用しているため抗原性の 観点から，そのまま臨床への応用は困難である。しかし，目的に応じた抗体を自在にマイクロバブル表 面に修飾できるため, 目的部位への抗体を利用したマイクロバブルのターゲティングに関するコンセプ 卜確認のために非常に有望な技術であると考えられる。これにより超音波造影に適した標的分子の候補 をスクリーニングした後に，アミド結合などの臨床応用が可能な抗体修飾方法に置換することでアク ティブターゲティング型マイクロバブルの開発スピードを加速できると期待されている. 実際に, Targeson 社はアビジンービオチンを介さない方法で抗体やペプチドを修飾したアクティブターゲティ ング型マイクロバブルの開発も手掛けている13,14). 


\section{ナノバブルの開発}

アクティブターゲティング型マイクロバブルの開発とともに並行して研究されているのが，マイクロ バブルよりサイズの小さいサブミクロンサイズのナノバブルの開発である. Rapoport ら15) Kawabata ら ${ }^{16)}$ は，がん組織深部まで到達する新たなナノバブルの開発を行っている．このナノバブル には，ガスとして生体内の温度では液体のパーフルオロペンタンやパーフルオロヘキサンなどが利用し されている，これはナノバブルの中でも特にナノ液滴と呼ばれており，このナノ液滴は温度や超音波の 刺激によりガス化してマイクロバブルを生じる新たなタイプの相変化 (液体 $\rightarrow$ 気体) 型バブルである. 現在，この相変化型バブルを利用したがん組織深部の造影や抗がん剂を保持させがん組織への超音波照 射による相変化誘導による抗がん剂デリバリーに関する研究が進められている．また，Pitt らは，この ナノ液滴を薬物キャリアーとして利用されているリポソーム (脂質二重膜の小胞 $)^{17)}$ に封入したナノ液 滴封入リポソーム (エコジェニックリポソーム) を開発している18,19). このエコジェニックリポソームに 薬物とナノ液滴を封入することで，超音波照射での相変化誘導による薬物放出制御が可能となる。一 方，著者らはリポソームに超音波造影用ガスであるパーフルオロプロパン (気体) を封入した超音波応 答性りポソーム (バブルリポソーム) を開発した。このバブルリポソームの平均粒子径は約 $500 \mathrm{~nm}$ であ り，脂質二重膜構造の内部に気泡が存在するユニークな構造をとっていた $(\mathrm{Fig} .1 \mathrm{~B}, \mathrm{C})^{20-22)}$. このバブ ルリポソーム表面には抗体やペプチドなどの標的指向性分子を容易に修飾可能であるため, アクティブ ターゲティング型ナノバブルの開発に適している，実際に共同研究者の根岸らは，がん細胞やがん組織 内の新生血管内皮細胞上に発現するシンデカンに親和性を有する AG73 ペプチドを修飾したバブルリ ポソームを開発し，がんの早期発見のための超音波造影剤開発を行っている ${ }^{23}$. また，萩沢らは，血栓 ターゲティング型バブルリポソームを開発し，血栓の超音波造影効果を増強することに成功した．この 検討では，血栓に存在する活性化血小板に対して親和性を有するアルギニン-グリシンーアスパラギン酸 (RGD) ペプチドを修飾したバブルリポソームを利用している，この RGD ペプチド修飾ナノバブルを 血栓 (下肢動脈) モデルウサギの耳介部の静脈から全身投与すると，このバブルリポソームが血栓に集 積するとともにマイクロバブルでは侵入できなかった血栓内部まで侵入して，血栓部分が超音波造影で 高エコーになることを報告している24).これが臨床応用されるようになれば，現在，X 線造影で行われ ている血栓造影を，放射線被ばくのない超音波造影に置き換えられる可能性があり，侵襲性の低い血栓 造影法の構築において重要な技術であると考元らる。いずれにしても，ナノバブルは既存のマイクロ バブルとは異なる領域への応用が期待されている.

\section{超音波治療の現状と課題}

超音波治療装置として, 超音波メスやがんに対するハイパーサーミアのための加温装置が利用されて いる，最近では，超音波エネルギーの集束技術およびその制御技術が進歩し，強力集束超音波 (HIFU： High Intensity Focused Ultrasound) によるがん治療システムが臨床応用されている ${ }^{25,26)}$. この HIFU は, 超音波エネルギーをがん組織に集束させ焦点部位の温度を上昇させることができるため，がん組織 を加熱凝固させることができる. 現在, この HIFUによるがん治療のターゲットとなっているのが, 前立腺がん ${ }^{27)}$ ，子宮筋腫 28$)$ や乳がん ${ }^{29)}$ である，これらの組織に対しては，経直腸的または体外から患 部に向けて超音波照射が行われている。このように HIFUによる治療は患者にとって侵襲性の低い治 療法である. しかし, HIFUによる治療では数 $\mathrm{mm}^{3}$ ずつがん組織を加熱凝固させていく必要がある上, 焦点以外での加熱を避けるため超音波を連続照射できず冷却時間が必要となっている．それ故，がん組 織のサイズに依存して治療時間が長くなってしまう30). 実際に臨床現場において前立腺がんを HIFU 
で治療するためには約 3 時間が必要とされており，治療を受けている間，患者は HIFU の焦点位置が ずれないように一定の体勢を維持している必要がある．また，超音波照射強度 $\left(0.5 \sim 1 \mathrm{~kW} / \mathrm{cm}^{2}\right)$ が高い ためプローブに近い皮膚などの焦点部位以外に対する傷害性が問題となっている. そのため, HIFUで 利用されている超音波照射強度より低い強度で広域のがん細胞を傷害できる温熱療法の構築が望まれて いる.

\section{ソノポレーション効果の増強について}

液体中に超音波を照射すると低圧と高圧が交互に発生し，低圧時の圧力によって空洞 (キャビティー) すなわち気泡が生じる現象が知られている (Fig. 2).このときの気泡内部は液体蒸気や液中に溶存した 気体であり, 圧力の変動に伴って気泡が成長, 圧壊する. 非常に低強度の超音波照射において, 気泡は 超音波の疎密波の中で振動するのみである (Fig. 2A). 超音波強度を少し高めると, 低強度の超音波照 射において気泡は振動し, 気泡内圧が外液の圧力に打ち負けた時に気泡の急激な収縮が生じる. これが 安定型キャビテーションと呼ばれている (Fig. 2B). また，さらに高強度の超音波を照射した場合，気 泡の振動に加え気泡サイズの増大が認められ, 気泡内圧が外液の圧力に打ち負けた時に気泡の急激な圧 壊が生じる。この時の圧壊現象は, 崩壊型キャビテーションと呼ばれており, この時に微視的な高温や ジェット流さらには水分子の分解による活性酸素の生成などが起こる (Fig. 2C). この現象が細胞近傍 で生じた場合，このエネルギーにより細胞膜に小孔が開く，この現象はソノポレーションと呼ばれ，超

(A) Very low-intensity ultrasound

Compression

Rarefaction

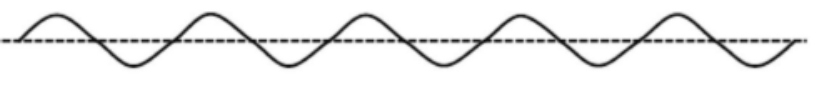

0000000000

(B) Low-intensity ultrasound (Induction of stable cavitation)

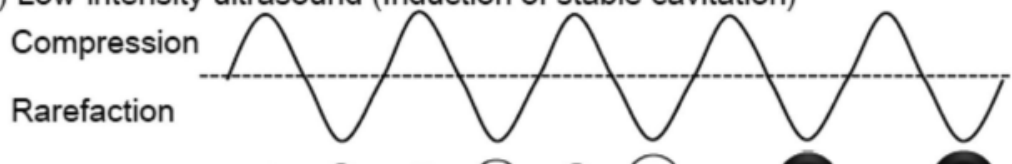

$000000 \cdot 0$

(C) High-intensity ultrasound (Induction of inertial cavitation)

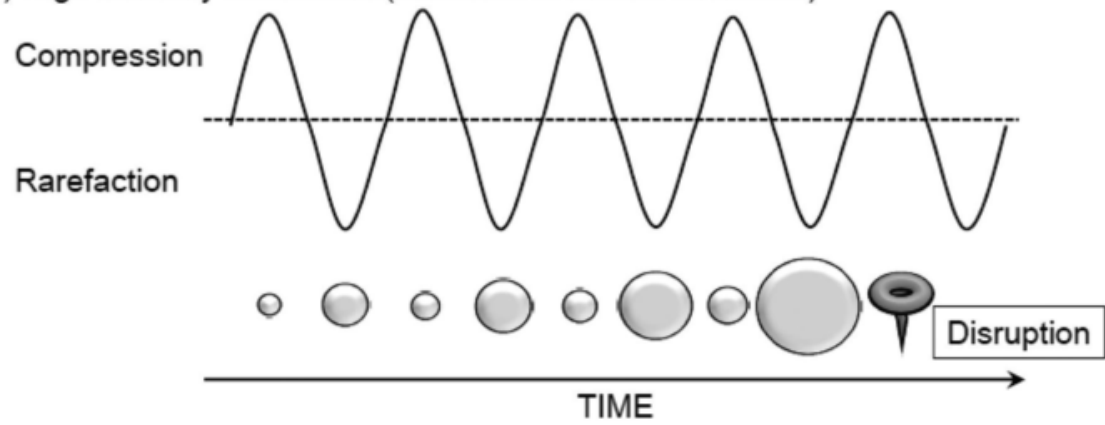

Fig. 2. Microbubble behavior in acoustic fields. (A) Very low-intensity ultrasound induces linear oscillation of the microbubble. (B) Low-intensity ultrasound induces oscillation of the microbubble with a gradual increase in microbubble diameter until it reaches a resonant diameter, the point at which stable cavitation occurs (filled black circles). (C) High-intensity ultrasound causes a rapid increase in the diameter of the microbubble for a few cycles, which induces bubble disruption (inertial cavitation). 
音波照射強度の最適化により，細胞を生存させたまま薬物や遺伝子を細胞内にデリバリーするために利 用されている ${ }^{31,32)}$ 。このソノポレーション効果は，マイクロバブルやナノバブルのような微小気泡と超 音波の併用により増強される，微小気泡があらかじめ存在する液体に超音波照射すると，崩壊型キャビ テーションを誘導することのできる超音波エネルギーの閾值が低下することが知られている．すなわち 低い超音波エネルギーで効率よく崩壊型キャビテーションを誘導可能になる. この微小気泡の崩壊型 キャビテーション誘導時にも, 気泡の圧壊に伴い気泡周囲にマイクロジェット流や発熱, 活性酸素の生 成が起こる．このように，超音波照射下での微小気泡の振る舞いにより加熱作用・機械作用・化学作用 が増強される。それわえ，微小気泡と超音波を併用することでHIFUより低い超音波照射強度で微小 気泡が存在している領域のがん細胞を傷害できるようになると考えられる.

\section{低強度超音波と微小気泡の併用によるがん温熱治療}

微小気泡により超音波エネルギーが熱に変換されるメカニズムは以下の 2 つが考えられている. (1)気 泡の周囲の液体の粘性により気泡と界面で気泡の振動エネルギーが熱に変換，(2微小気泡が振動を繰り 返しているときの振動エネルギーが気泡内部の気体の熱に変換である. 実際にマイクロバブルと低強度 超音波の併用により温度上昇効率の向上が報告されている ${ }^{33,34)}$. Umemura らは, 直径 $0.25 \mathrm{~mm}$ の熱電 対をラット腎藏に刺入して，マイクロバブル (オプチゾン) $0.25 \mathrm{mg} / \mathrm{kg}$ で投与直後に周波数 $3.2 \mathrm{MHz}$, 強度 $0.29 \mathrm{~kW} / \mathrm{cm}^{2}$ の集束超音波を 10 秒間照射すると，マイクロバブル投与前の集束超音波単独では $42^{\circ} \mathrm{C}$ 程度までの温度上昇であったものが，約 $73^{\circ} \mathrm{C}$ まで昇することを報告している ${ }^{35}$. このよ うにマイクロバブルと低強度集束超音波により温 度上昇効率を増強できることが明らかとなった。 この温度上昇効果がナノバブルとさらに低強度の 超音波照射でも誘導できるかを検討した。この検 討では，担がんモデルマウスを用い，バブルリポ ソームと非集束超音波照射 $\left(4 \mathrm{~W} / \mathrm{cm}^{2}\right)$ によるが ん組織内の温度上昇を評価した (Fig. 3)。 その結 果, がん組織に超音波のみを照射した場合, がん 組織内温度は約 $38.5^{\circ} \mathrm{C}$ (約 $5.5^{\circ} \mathrm{C}$ 上昇) となった. また，バブルリポソーム存在下で超音波照射を行 うと, がん組織内温度が約 $44^{\circ} \mathrm{C}$ (約 $11^{\circ} \mathrm{C}$ 上昇) に 達した。このがん組織内の温度上昇は, バブルリ ポソームのキャビテーション誘導に伴うものであ ると考元られた，一般に温熱処理による細胞致死 効果は $42.5^{\circ} \mathrm{C}$ 境目に $1^{\circ} \mathrm{C}$ 温度上昇によって, 数百倍に向上することが知られている ${ }^{36,37)}$. この ことを考慮すると, バブルリポソームのキャビ テーションが，がん組織内温度上昇による温熱効 果とジェット流によるソノポレーション効果の相 乗効果で効率よくがん細胞死を誘導できると考元 られる，そこで，このバブルリポソームと超音波

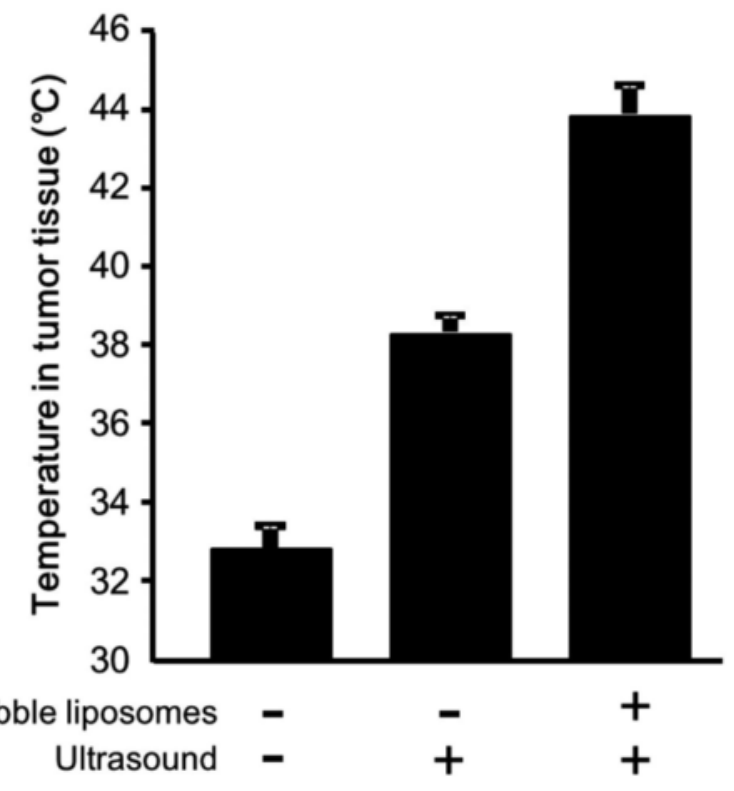

Fig. 3. Temperature in the tumor tissue increases with ultrasound exposure to Bubble liposomes. Colon- 26 cells $\left(1 \times 10^{6}\right.$ cells $)$ were subcutaneously inoculated into mice. After 8 days, Bubble liposomes were injected into the tumor tissue. The tissue was then transdermally exposed to ultrasound ( $\left.1 \mathrm{MHz}, 4 \mathrm{~W} / \mathrm{cm}^{2}, 2 \mathrm{~min}\right)$. To measure the temperature in the tumor tissue, a thermocouple was inserted into the tumor tissue. In this case, the data shows the temperature at 2 min from the start of ultrasound exposure. 
の併用によるがん治療効果を検討した (Fig. 4A，B)，その結果，超音波単独で治療した群では，ほとん どがん細胞の増殖抑制が認められなかった，一方，バブルリポソームと超音波の併用群では，顕著なが 几細胞の増殖抑制効果が認められた，実際に治療直後のがん組織を顕微鏡観察したところ，バブルリポ ソームと超音波の併用群において，がん細胞の壊死領域が認められた (Fig. 4C). このように，バブル リポソームと超音波の併用は, HIFU より低強度の超音波照射で, バブルリポソームが分布している領 域のがん細胞を傷害可能な方法として有用になると考えられた.

(A)

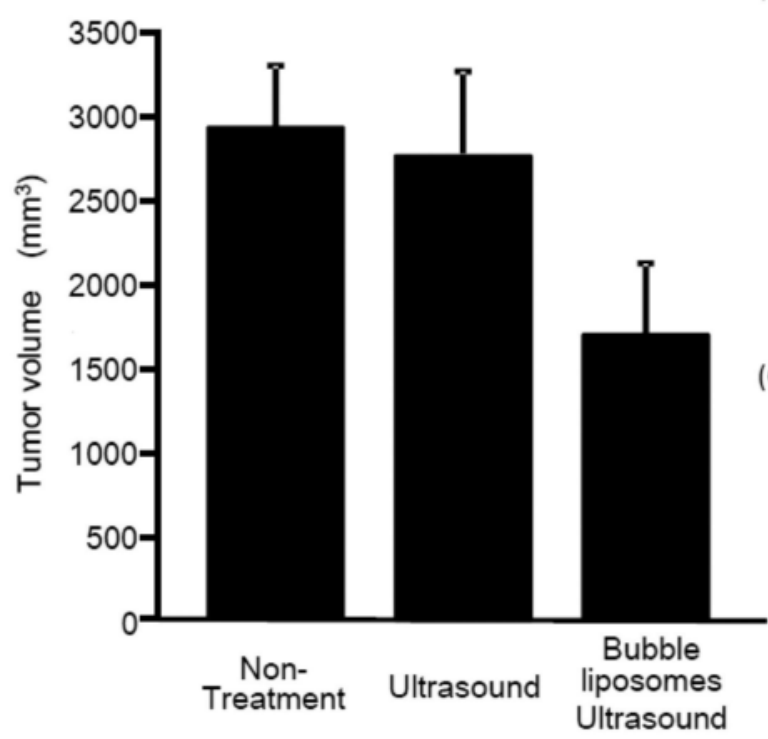

(B)

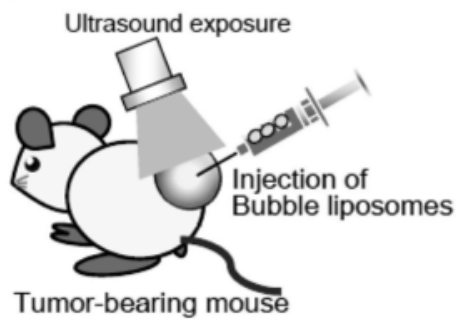

(C) Bubble liposome + Ultrasound

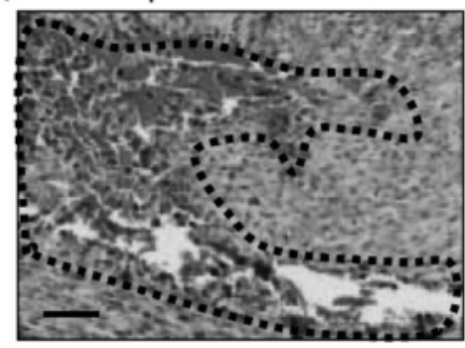

Fig. 4. Tumor growth is suppressed by ultrasound exposure to Bubble liposomes. Colon-26 cells $\left(1 \times 10^{6}\right.$ cells $)$ were subcutaneously inoculated into mice. After 8 days, Bubble liposomes were injected into the tumor tissue. The tissue was then transdermally exposed to ultrasound $\left(1 \mathrm{MHz}, 4 \mathrm{~W} / \mathrm{cm}^{2}, 2 \mathrm{~min}\right)$. Tumor growth was assessed by measuring the tumor volume. (A) The tumor volume at 27 days after tumor inoculation. (B) Schematic of hyperthermia with ultrasound and Bubble liposomes. (C) Hematoxylin and Eosin (H \& E) staining of the tumor tissue that was treated with Bubble liposomes and ultrasound. The area within the dotted line shows the necrotic area. Scale bar $=50 \mu \mathrm{m}$.

\section{今後の展望}

温熱療法が近代医学に登場してきてから三十数年が経過し，様々な分野で研究が行われている．それ に伴い，加温装置や治療法が発達してきた，そのなかで，HIFU を用いたがん温熱療法は子宮筋腫や前 立腺がんに対して低侵襲的に温熱治療を行うことのできる有望ながん治療法の 1 つとして認知されつつ ある.この HIFU によるがん治療には治療時間や正常組織への傷害などの課題が残されてはいるもの の，マイクロバブルやナノバブルと併用することでこれら問題を解決する糸口が見えつつある. 将来的 には，がん組織特異的に集積するアクティブターゲティング型ナノバブルでがんの早期超音波診断を行 い，がん組織に集積した低強度集束超音波による崩壊型キャビテーション誘導を利用した温熱療法の開 発が可能になると考えられる，これこそが，理想的な超音波セラノスティックスであり，今後の発展が 期待される. 


\section{参考文献}

1) Chen X.S. : Introducing Theranostics Journal - From the Editor-in-Chief. Theranostics, 1: 1-2, 2011.

2) Kiessling F., Fokong S., Koczera P., Lederle W., Lammers, T.: Ultrasound microbubbles for molecular diagnosis, therapy, and theranostics. J Nucl Med, 53: 345-348, 2012.

3) Gramiak R., Shah P.M. : Echocardiography of the aortic root. Invest Radiol, 3 : 356-366, 1968.

4) Mulvagh S.L., DeMaria A.N., Feinstein S.B., Burns P.N., Kaul S., Miller J.G., Monaghan M., Porter T.R., Shaw L.J., Villanueva F.S. : Contrast echocardiography: Current and future applications. J Am Soc Echocardiogr, 13: 331-342, 2000.

5) Nicolau C., Vilana R., Catala V., Bianchi L., Gilabert R., Garcia A., Bru C. : Importance of evaluating all vascular phases on contrast-enhanced sonography in the differentiation of benign from malignant focal liver lesions. JR Am J Roentgenol, 186: 158-167, 2006.

6) Watanabe R., Matsumura M., Munemasa T., Fujimaki M., Suematsu M. : Mechanism of hepatic parenchyma-specific contrast of microbubble-based contrast agent for ultrasonography: Microscopic studies in rat liver. Invest Radiol, 42 : 643-651, 2007.

7) Watanabe R., Matsumura M., Chen C.J., Kaneda Y., Fujimaki M.: Characterization of tumor imaging with microbubble-based ultrasound contrast agent, sonazoid, in rabbit liver. Biol Pharm Bull, 28 : 972-977, 2005.

8) Watanabe R., Matsumura M., Chen C.J., Kaneda Y., Ishihara M., Fujimaki M. : Gray-scale liver enhancement with Sonazoid (NC100100), a novel ultrasound contrast agent; detection of hepatic tumors in a rabbit model. Biol Pharm Bull, 26 : 1272-1277, 2003.

9) Omoto K., Matsunaga H., Take N., Hozumi Y., Takehara M., Omoto Y., Shiozawa M., Mizunuma H., Harashima H., Taniguchi N., Kawano M. : Sentinel node detection method using contrast-enhanced ultrasonography with sonazoid in breast cancer : preliminary clinical study. Ultrasound Med Biol, 35 : 1249-1256, 2009.

10) Pochon S., Tardy I., Bussat P., Bettinger T., Brochot J., von Wronski M., Passantino L., Schneider M. : BR55: A lipopeptide-based VEGFR2-targeted ultrasound contrast agent for molecular imaging of angiogenesis. Invest Radiol, 45: 89-95, 2010.

11) Tardy I., Pochon S., Theraulaz M., Emmel P., Passantino L., Tranquart F., Schneider M.: Ultrasound molecular imaging of VEGFR2 in a rat prostate tumor model using BR55. Invest Radiol, 45 : 573-578, 2010.

12) Pysz M.A., Foygel K., Rosenberg J., Gambhir S.S., Schneider M., Willmann J.K.: Antiangiogenic cancer therapy: Monitoring with molecular US and a clinically translatable contrast agent (BR55). Radiol, 256 : 519-527, 2010.

13) Anderson C.R., Hu X., Zhang H., Tlaxca J., Decleves A.E., Houghtaling R., Sharma K., Lawrence M., Ferrara K.W., Rychak J.J.: Ultrasound molecular imaging of tumor angiogenesis with an integrin targeted microbubble contrast agent. Invest Radiol, 46 : 215-224, 2011.

14) Anderson C.R., Rychak J.J., Backer M., Backer J., Ley K., Klibanov A.L. : scVEGF microbubble ultrasound contrast agents: A novel probe for ultrasound molecular imaging of tumor angiogenesis. Invest Radiol, 45: 579-585, 2010.

15) Rapoport N.Y., Kennedy A.M., Shea J.E., Scaife C.L., Nam K.H.: Controlled and targeted tumor chemotherapy by ultrasound-activated nanoemulsions/microbubbles. J Control Release, 138: 268-276, 2009.

16) Kawabata K., Asami R., Azuma T., Yoshikawa H., Umemura S. : Anti-tumor effects of cavitaion induced with phase-charge nano droplet and ultrasound. 2009 IEEE International Ultrasonics Symposium, pp.208-211, 2009.

17) Barenholz Y.: Doxil--the first FDA-approved nano-drug: Lessons learned. J Control Release, 160 : 117-134, 2012.

18) Javadi M., Pitt W.G., Tracy C.M., Barrow J.R., Willardson B.M., Hartley J.M., Tsosie N.H. : Ultrasonic gene and drug delivery using eLiposomes. J Control Release, 167 : 92-100, 2013.

19) Javadi M., Pitt W.G., Belnap D.M., Tsosie N.H., Hartley J.M. : Encapsulating nanoemulsions inside eLiposomes for ultrasonic drug delivery. Langmuir, 28 : 14720-14729, 2012. 
20) Suzuki R., Takizawa T., Negishi Y., Utoguchi N., Sawamura K., Tanaka K., Namai E., Oda Y., Matsumura Y., Maruyama K.: Tumor specific ultrasound enhanced gene transfer in vivo with novel liposomal bubbles. J Control Release, 125 : 137-144, 2008.

21) Suzuki R., Takizawa T., Negishi Y., Hagisawa K., Tanaka K., Sawamura K., Utoguchi N., Nishioka T., Maruyama K. : Gene delivery by combination of novel liposomal bubbles with perfluoropropane and ultrasound. J Control Release, 117: 130-136, 2007.

22) Kodama T., Tomita N., Horie S., Sax N., Iwasaki H., Suzuki R., Maruyama K., Mori S., Fukumoto M. : Morphological study of acoustic liposomes using transmission electron microscopy. J Electron Microsc (Tokyo), 59: 187-196, 2010.

23) Negishi Y., Hamano N., Tsunoda Y., Oda Y., Choijamts B., Endo-Takahashi Y., Omata D., Suzuki R., Maruyama K., Nomizu M., Emoto M., Aramaki Y.: AG73-modified Bubble liposomes for targeted ultrasound imaging of tumor neovasculature. Biomater, 34 : 501-507, 2013.

24) Hagisawa K., Nishioka T., Suzuki R., Takizawa T., Maruyama K., Takase B., Ishihara M., Kurita A., Yoshimoto N., Ohsuzu F., Kikuchi M.: Enhancement of ultrasonic thrombus imaging using novel liposomal bubbles targeting activated platelet glycoprotein IIb/IIIa complex - in vitro and in vivo study. Int J Cardiol, 152 : 202-206, 2011.

25) Al-Bataineh O., Jenne J., Huber P. : Clinical and future applications of high intensity focused ultrasound in cancer. Cancer Treat Rev, 38 : 346-353, 2012.

26) Kennedy J.E. : High-intensity focused ultrasound in the treatment of solid tumours. Nat Rev Cancer, $5: 321-327,2005$.

27) Thuroff S., Chaussy C. : Evolution and outcomes of $3 \mathrm{MHz}$ high intensity focused ultrasound therapy for localized prostate cancer over 15 years. J Urol, 2013. in press

28) Hesley G.K., Gorny K.R., Woodrum D.A.: MR-guided focused ultrasound for the treatment of uterine fibroids. Cardiovasc Intervent Radiol, 36: 5-13, 2013.

29) Napoli A., Anzidei M., Ciolina F., Marotta E., Cavallo Marincola B., Brachetti G., Di Mare L., Cartocci G., Boni F., Noce V., Bertaccini L., Catalano C.: MR-guided high-intensity focused ultrasound: Current status of an emerging technology. Cardiovasc Intervent Radiol, 2013.

30) Chung D.J., Cho S.H., Lee J.M., Hahn S.T.: Effect of microbubble contrast agent during high intensity focused ultrasound ablation on rabbit liver in vivo. Eur J Radiol, 81 : e519-523, 2012.

31) Taniyama Y., Tachibana K., Hiraoka K., Namba T., Yamasaki K., Hashiya N., Aoki M., Ogihara T., Yasufumi K., Morishita R. : Local delivery of plasmid DNA into rat carotid artery using ultrasound. Circ, 105 : 1233-1239, 2002.

32) Oda Y., Suzuki R., Otake S., Nishiie N., Hirata K., Koshima R., Nomura T., Utoguchi N., Kudo N., Tachibana K., Maruyama K. : Prophylactic immunization with bubble liposomes and ultrasound-treated dendritic cells provided a four-fold decrease in the frequency of melanoma lung metastasis. J Control Release, 160 : 362-366, 2012.

33) Fujishiro S., Mitsumori M., Nishimura Y., Okuno Y., Nagata Y., Hiraoka M., Sano T., Marume T., Takayama N. : Increased heating efficiency of hyperthermia using an ultrasound contrast agent : A phantom study. Int J Hyperthermia, $14: 495-502,1998$.

34) Razansky D., Einziger P.D., Adam D.R. : Enhanced heat deposition using ultrasound contrast agent-modeling and experimental observations. IEEE Trans Ultrason Ferroelectr Freq Control, 53: 137-147, 2006.

35) Umemura S., Kawabata K., Sasaki K. : In vivo acceleration of ultrasonic tissue heating by microbubble agent. IEEE Trans Ultrason Ferroelectr Freq Control, 52 : 1690-1698, 2005.

36) Roti Roti J.L.: Cellular responses to hyperthermia (40-46 degrees C) : Cell killing and molecular events. Int J Hyperthermia, $24: 3-15,2008$

37) Dewey W.C., Hopwood L.E., Sapareto S.A., Gerweck L.E. : Cellular responses to combinations of hyperthermia and radiation. Radiol, 123 : 463-474, 1977. 